\title{
The Financing of Mine Land Rehabilitation in the Czech Republic
}

\author{
J. Dvořáček VŠB - Technical University of Ostrava, Czech Republic
}

J. Štěrba Larumo Mining - CZ, s.r.o., Czech Republic

K. Novotný Gemec-Union, a.s., Czech Republic

\begin{abstract}
Mining operations in the Czech Lands have a very long history. The first mining legislation was adopted more than seven centuries ago; in the 19th century the topic of the rehabilitation of land was included. Since the 1990s the rehabilitation of land has been given special attention in the Mining Act of 1991 in an effort to deal with the environmental issues related to mining operations. The paper discusses the rehabilitation of land and reclamation of areas affected by underground and opencast coal mining, and by the extraction of ores and uranium currently in the Czech Republic. It describes the trend of the financing methods of the rehabilitation and reclamation in recent decades under the conditions of transfer of a central planning national economy to a market economy. The paper deals with the reserve funds devoted to removal of the damages caused by mining, the rehabilitation of land and reclamation of areas affected by mining which are accumulated in accordance with the current mining and economic legislation. It addresses the potential problems related to the recent requirement for building-up of reserve funds in financial form and depositing them in a special tied bank account. Problems of financial guarantees for the rehabilitation of land are also discussed. Emphasis is laid on the importance of progressive rehabilitation of land as a method of diminishing the blockage of funds set aside for rehabilitation purposes.
\end{abstract}

\section{Introduction}

Mining has a very long history in the territory of the present Czech Republic. The first principles of the mining law were laid down as early as the mid-13th century. The extraction of ores of gold, silver and other metals was later overtaken by coal mining and after World War II by the extraction of uranium. Centuries of mining have brought about damage to the land and even the recent mining operations have adverse effects. The growing extent of these effects has initiated the introduction of certain terms, such as the damage caused by mining and the rehabilitation and reclamation of land into the mining legislation. Damages caused by mining are considered to be damages to real estate caused by prospecting and exploitation of deposits including the loss of surface and underground water. The rehabilitation of land is considered to be the elimination of the damage to the landscape by complex treatment of territory. Rehabilitation also includes reclamation of the areas affected by mining, i.e. the restoration of the desired condition of the devastated areas by means of implementing measures of a technical nature (ground shaping, stream restoration, drainage) and biological nature (revegetation, arable crop seeding, ponds). The Mining Act began to deal with the reclamation of affected areas in the 19th century. Ever since the 1990s, the reclamation of land has been paid special attention in an effort to tackle the environmental problems related to mining activity.

However, the elimination of the damage caused by mining as well as the rehabilitation and reclamation of the affected areas are very costly. Some of the operations are carried out after the extraction has been terminated and that is why the funds required for their execution have to be amassed in advance. Therefore, the mining legislation has prescribed the creation of the reserve funds for these activities.

The financing of the rehabilitation and reclamation of land has been influenced by the state ownership of mining companies from the end of World War II to the early 1990s and the subsequent privatization of the majority of mining operations. The damping and the restructuring of the mining industry, which started in the 1990s, have also played an important role. Damping of mining industry is a government programme focused on decreasing of mining industry production and mines closing. It covers technical liquidation of mines (e.g. shafts filling, surface facilities demolition) and solution of mining activities consequences in both social and environmental area. 


\section{Rehabilitation and reclamation of land in the mining legislation}

The basic element of the mining legislation in the Czech Republic is the Act on the protection and utilization of mineral resources (the Mining Act) passed in 1988 and amended several times since then. Its purpose is to lay down the principles of the protection and economic use of mineral resources. Mineral resources consist of the deposits of reserved minerals (energy-producing raw materials, ores, precious stones, rocks etc.), which are owned by the state. The deposits of non-reserved minerals constitute an integral part of land (i.e. belong to the land owner).

To be able to commence the extraction of the deposit of reserved minerals (i.e. the reserved deposit), a mining company has to be a holder of, among others, a permit for mining operations issued by a body of the State Mining Administration - the District Mining Authority. In addition, the organization is obliged to prepare a development and extraction plan for the reserved deposits. The plan has to include a calculation of estimated costs of the compensation for the damage caused by the activities planned, and of the rehabilitation and reclamation of the areas affected by mining and related activities. The organization is also obligated to propose the amount and the method of amassing the funds.

In the case of opencast mining, the rehabilitation of land involves the stabilization of quarry faces, the treatment of the front zone, the dump and other areas, reclamation work, pumping of water, treatment of discharged water, land drainage, while in the case of underground mining it comprises the liquidation of the affected parts of the built-up area, the relocation of underground services, the shaping of the area, the reclamation of the land, slurry ponds drainage, treatment of water etc. In the course of opencast mining the rehabilitation of land and the liquidation of a quarry are integrated. However, in the case of underground mines, the Mining Act does not explicitly define the liquidation of a mine as a part of the rehabilitation work; it is dealt with by other acts which regulate mining. In practice, the liquidation of an underground mine and the rehabilitation of land are executed separately.

The Mining Act also introduces the term "old workings", which refers to abandoned underground mine works or quarries where the extraction of reserved minerals has been terminated and whose original operator and legal successor do not exist or are unknown. The safeguarding or liquidation of old workings to the required extent is carried out by the Ministry of the Environment of the Czech Republic.

\subsection{The rehabilitation and reclamation of land in relation to opencast coal mining}

The beginnings of the reclamation of land date back to opencast mining at the time when the Czech Lands were part of the Austro-Hungarian Empire. The 1854 Mining Act dealt with, among other things, the approach of miners towards the land; it demanded that the land affected by mining should return to the original purpose and determined the methods of elimination of the damage caused by mining. The first organized recovery of land affected by mining was carried out in North Bohemia in 1908. In 1957 a plant specialized in the reclamation of land was founded for opencast lignite coal mines.

The initial reclamation work only focused on the recovery of agricultural land, cultivation on waste dumps and retrieval of surface soil. As opencast mining affected whole regions, the so-called General Reclamation Plan was drawn up in the late 1950s. In the 1990s the reclamation process was aimed at improving the affected areas with new landscape formations with the possibility of creating new links in the environmental and social spheres. Thus, the main objective of the reclamation of land is to restore and create agricultural land, agricultural and forest plantations, water areas (ponds, lakes) and streams as well as recreational and commercial areas. The future use of the area is the determining factor.

\subsection{The rehabilitation and reclamation of land in relation to underground coal mining}

Underground coal mining affects the countryside primarily by causing surface subsidence and producing mine dumps and slurry ponds.

A typical effect of the underground extraction of coal deposits is the deformation of the Earth's surface above the worked-out areas. The extent of surface changes depends on the thickness of coal seams, depth of the workings, size of the worked-out area and the intensity of exploitation. The changes occurring on the surface do not cease with the termination of mining operations, but continue for some time afterwards. 
Initially, mine dumps were of a conical shape and considerable height to minimize their surface footprint. Since the 1950s flat or terraced mine dumps have been produced with a view to creating the conditions for their integration in the countryside or for further use.

Slurry ponds were used for the deposition of fine coal particles dispersed in water from the treatment of extracted coal. These particles are no longer produced as the coal treatment process has been modified. Slurry ponds have been worked out and have gone through the rehabilitation and reclamation process.

Generally, the rehabilitation and reclamation work represents radical and costly intervention in the landscape. The result of the technical reclamation is the shaping of the area, the restoration of water streams, the relocation of underground services and subsequent biological restoration for the purpose of setting up agricultural, forest and other plantations, and/or water dams in the devastated areas.

\subsection{The rehabilitation and reclamation of land in relation to the underground extraction of metals and uranium}

The liquidation of all metal mines in the Czech Republic began in the early 1990s and has now been completed. The extraction of uranium has been subjected to a similar process, where just one mine (stateowned) has remained operating.

In the case of metal mines, the rehabilitation and liquidation operations comprise the liquidation of all production and treatment capacities, and the subsequent removal of the adverse effects of the extraction and treatment of ores on the environment.

In the case of the extraction of uranium, rehabilitation and closure mainly includes:

- The elimination of the impact of the uranium industry: technical liquidation of the underground and surface parts of production capacities, taking care of environmental damage, pumping and treatment of contaminated water, taking care of environmental damage caused by works closed down before the damping of the uranium and ore industries was announced.

- Rehabilitation operations including investments in the environment in the areas affected by the chemical extraction of uranium.

The rehabilitation and reclamation operations are prepared and carried out in collaboration with the District Mining Authority, municipal authorities and the Ministry of the Environment of the Czech Republic. The issues tackled are the protection and the recovery of the agricultural and forest land resources, and the future impact of mining on the environment (Šanda, 2006).

\section{The financing of the rehabilitation and reclamation of land}

Ensuring that funds are available for eliminating the negative impacts of mining operations has been influenced by the economic management system and the property situation in the national economy and thus in the mining industry.

After World War II the mining industry was nationalized and a system of planned central economic management was established. The then legislation laid a duty on mining companies to agree with the authorities on the scope and the quality of the recovery of the areas belonging to the agricultural and forest land resources. The rehabilitation which included reclamation as well was financed from the Damage and Compensation Fund. The Fund was defined as the means for the elimination of damage to the property of state organizations and persons, which was caused by the prospecting and exploration of deposits, the building and/or liquidation of mine works and facilities, and the extraction and processing of minerals. The Funds were created under the state plan from the contributions made by mining companies and reported as expenditures. The Damage and Compensation Fund was company property and was of a strictly special purpose nature. The amassing of the Fund had no direct link with the expected expenditure. The situation changed by the end of 1990 .

After 1990 the technical reclamation work was to be covered by investments. An exception applied to opencast coal mining, which made it possible to treat the funds as expenditure. The validity of the exception expired towards the end of 1992. 
However, at that time the damping and restructuring of the mining industry was under way. Year 1990 marked the damping of metal mining industry, in 1991 the concept of the extraction of uranium was modified and in 1992 the restructuring of the coal mining industry began. Those processes were the result of the changed attitude of the state towards the exploitation of the metal deposits, uranium and coal under the new economic situation. The objective of the restructuring of the coal mining industry was to create the conditions for the foundation of private and competitive companies. Poorly performing companies were supposed to be dissolved. In conjunction with the damping, subsidies were granted from the state budget to ensure, among others, the rehabilitation of the impact of mining operations. Later, the subsidies were only granted to two mining companies, which were state-owned.

Coal mining companies, too, were provided with subsidies for the rectification of the damage to the environment caused by the extraction of reserved deposits - the Environmental Subsidies. The source of the subsidies was the state's income from the minerals extracted - royalties.

The amended Mining Act passed in 1991 brought about a radical change in the financing of the rehabilitation and reclamation of land. It laid a duty on organizations to arrange for the rehabilitation of the land affected by mining and to maintain reserve funds to provide for closure. The creation of the reserve fund is reported as expenditure; the amount of the fund has to be adequate for the requirements of the rehabilitation of land. The Mining Act as amended made reclamation an integral part of the rehabilitation; the reserve fund maintained for these operations is deductible. Ever since 1993 the calculation of the estimated costs of the compensation for the damage caused by mining and of the rehabilitation and reclamation of the areas affected as well as the proposal of the funds required has been a part of the development and extraction plan. The reserve funds for the rehabilitation and reclamation of land are amassed by means of surcharging the cost of each ton of the coal extracted or by an annual amount fixed for the period of the authorization to carry out mining operations. The creation of the reserve funds for the rehabilitation and reclamation of the affected areas is subject to approval from the District Mining Authority, which, as a body of the State Mining Administration, is also in charge of authorizing the use of the funds upon agreement with the Ministry of the Environment of the Czech Republic (Stiebitz, 2001).

The amount of the reclamation cost and thus the amount of the reserve fund for the rehabilitation and reclamation of land depends on the requirements for the future use of the area. The particular rehabilitation and reclamation operations are updated every year in accordance with the approved development and extraction plans. The reserve funds are earmarked and must not be used for any other purposes. However, the Mining Act failed to determine the method of creating the reserve funds. Until the end of 2003 the reserve funds could either be kept in money accounts or recorded in the books without quick assets (e.g. money on deposit) being available, e.g. by means of the covering by selected tangible assets (Spurný, 2005).

However, when a mining company goes bankrupt, its assets cannot be sold in many cases and the obligations to rehabilitate the effects of mining activity have to be met by the state. From a legal point of view, the situation is solved as follows: an abandoned working without an owner or the owner's legal successor becomes an old working and devolves to the Ministry of the Environment by virtue of the relevant section in the Mining Act. Thus, the cost of securing or liquidation of the mine works is carried over to the state, i.e. taxpayers.

Ever since 2004 the reserve funds for the compensation of damage caused by mining and the rehabilitation and reclamation of the areas affected have had to be created in the form of ready money. The funds are deposited in a special bank account and must not become collateral or a part of the bankrupt's estate. The funds can be temporarily carried over to other assets or to the Ministry of Finance to increase the revenues. However, only the funds deposited in a special account are tax deductible. The revenues from the funds are exempted from income tax.

The above-mentioned amendment to the Mining Act has prompted a lively discussion within the mining industry. The reserve funds for the rehabilitation and reclamation of land reported by large companies engaged in opencast coal mining amount to tens of millions of US\$.

The methods of creation of the reserve funds may vary depending on whether mining organizations keep accounts in accordance with the International Financial Reporting Standards or the accounting legislation of the Czech Republic. 
The former applies to joint-stock companies in the European Union whose shares are publicly traded on a stock exchange. The reserve fund is created by depreciations of the revaluated fixed assets. The revaluation corresponds to the present value of the future cost of the rehabilitation work and it is annually adjusted to the trend in prices and interest rates.

Joint-stock companies, whose securities may not be offered for sale to the general public in the Czech Republic, and other types of companies, create the reserve funds in conformity with the Czech legislation. In this case, the funds are reported as expenditures.

\section{Discussion}

The amendment to the Mining Act based on the amended act regulating provisions was accompanied by conflicting attitudes of the Ministry of Finance on one side and the professional association of mining companies on the other.

Arguments presented by the Ministry of Finance:

- The state should not bear the costs of the reclamation of land for companies which have failed to discharge their duties.

- Experience has shown that the reserve funds created in the books were covered by immovables which could not be converted to money once the financing of the rehabilitation of land was required.

Arguments presented by mining companies:

- The law enables interpretation in terms of the additional taxation of the reserve funds which will not be deposited in the form of cash in the special tied account.

- There are old obligations to carry out rehabilitation and reclamation work, which had not been fulfilled before the privatization of mining companies and which were not taken into account when the price of the companies offered in the privatization process was being set.

- The cash reserve funds will block enormous financial means for a long time, especially in the case of large mining companies.

- Having the reserve funds within its powers, the state may use them to finance other activities, thus making the means unavailable for the reclamation work when required.

An attitude to the above arguments can be taken upon the ascertaining of the share of the reserve funds for the rehabilitation and reclamation of land in the financing of the company assets. The funds are reported in external sources of the balance sheet on the liability side, which records the sources of financing of the company assets.

Twenty-seven mining companies (approximately $8 \%$ of mining organizations in the Czech Republic) were taken as a pilot sample. The sample included all the largest mining companies in the Czech Republic and some of the medium- and small-sized enterprises. The findings of the survey are as follows:

- The share of the reserve funds in the liabilities of a large company engaged in underground coal mining is comparatively low - about $3.5 \%$ - as a result of the relatively small allotment compared to opencast coal mining.

- The share of the reserve funds in the liabilities of large mining companies (with assets of more than US\$ 100 million) is over $22 \%$ on average.

- The share of the reserve funds in the liabilities of small mining companies (with assets of far less than US\$ 100 million) is about 5\% on average; with the smallest companies (with assets of less than US\$ 17 million) the share amounts to tenths of a per cent.

It can be established that the smaller the size of a company, the lower the share of the reserve funds in liabilities, and thus the lower the source of financing of the company assets. Exceptions do exist, though. The share of the reserve funds in the liabilities of a medium-sized company corresponded to the share in the 
smallest companies, while the share in one of the smallest companies was more than $90 \%$. In this case the reserve creation is absolutely fictitious.

Even though the number of the companies, which were a part of the survey, was low, it can be established that there is a danger of small mining companies being unable to meet their obligations in terms of the rehabilitation and reclamation of the areas affected by mining. The reason is a very low reserve fund or its fictitious nature without any real possibility of creating the financial means for the reclamation work after mining operations are terminated.

\section{Conclusion}

The basic problem of the financing of the rehabilitation and reclamation of land in the Czech Republic is considered to be the continuous creation of the reserve funds for these operations. The reserve funds are supposed to be available in full before the mining activity is terminated.

The problem does not apply to large mining companies, which maintain tens of millions of US\$ in their reserve funds, which have ample property and are able to create sufficient cash-flow. However, the situation is different for small mining companies where the absolute value of the reserve funds is very low and where no financial guarantees are available to the State Mining Administration for the discharge of obligations stipulated by the mining legislation. In some cases the reserves are fictitious.

On the other hand, it must be pointed out that the amount of the reserve funds to be created depends on the actual activity in this field and is continuously updated according to the development of opinions of the desired condition of the area and the trend in the costs of the particular operations.

Another problem is the fact that the reserve funds only concern the deposits of reserved minerals and the deposits of non-reserved minerals regarded as convenient for the national economy.

The long-term blocking of financial means can be reduced (maintaining the rehabilitation standards) by way of progressive rehabilitation of the areas affected by mining. It can be assumed that all the deposits are over their mining peak by now and the area affected by mining is decreasing, e.g. the area affected by the activity of a large company engaged in opencast coal mining has decreased by $37 \%$ over the last eight years.

The cases of the cost of the rehabilitation and reclamation of land being fully carried over to the state have not posed any major problems in the Czech Republic so far due to the fact that:

- There are financial means that are earmarked from state budget for the rectification of the damage to the environment and are in assistance to the regions affected by intensive mining in the past.

- There is a category of "old workings" which comes under the Ministry of the Environment of the Czech Republic.

- The transfer of the allotment in unworked deposits between mining companies has involved the transfer of obligations to carry out the rehabilitation and reclamation of land.

Nevertheless, the State Mining Administration demands that environmental financial guarantees (i.e. funds fully available prior to mining commencement) should be implemented. These efforts will probably meet with opposition from mining companies as the implementation would affect their financial position by blocking of considerable financial means for years of mining activity. Therefore, the process is expected to be a long-term one and it will mainly be influenced by:

- The number of cases where environmental obligations are transferred to the state.

- The amount of money required for the discharge of the obligations.

\section{Acknowledgements}

The contribution was realized thanks to the financial support of the research centre of integrated system of utilization of by-product from extraction, processing and manufacturing of energy raw materials which is greatly appreciated. 


\section{References}

OKD, a.s. Životní prostředí (OKD, a.s.: The Environment) [online] [cit. 2008-01-11]. Available at: <http://www.okd.cz/cz/zivotní-prostredi/>.

Spurný, L. (2005) Využívání vytvořených prostředků na sanace a rekultivace. In: Tvorba finančních rezerv - sanacerekultivace. Most, str. 6-9. (The Use of the Funds Created for the Purpose of the Rehabilitation and Reclamation of Land. In: The Creation of the Reserve Funds - Rehabilitation and Reclamation, Most, pp. 6-9).

Stiebitz, J. (2001) Současný stav zahlazování důsledků hornické činnosti formou sanací a rekultivací včetně některých problémů spojených s touto činností (The Current Situation in the Elimination of the Effects of Mining by the Rehabilitation and Reclamation of Land Including Some of the Related Issues) [online] [cit. 2008-01-22]. Available at: <http://www.diamo.cz/hpvt/2001/index.html>.

Šanda V. (2006) Útlum hornictví včetně sanace těžby uranu v ČR (The Recession of the Mining Industry and the Recovery of Extraction of Uranium in the CR.) [online] [cit. 2008-01-12]. Available at: <http://www.mpo.cz/dokument 8065.html>.

Úplné znění zákona č. 44/1988 Sb. o ochraně a využití nerostného bohatství (horní zákon) (Full version of Act N.44/1988 Coll. on the protection and utilization of mineral resources (The Mining Act)) [online] [cit. 2008-0122]. Available at: 〈http://www.cbusbs.cz/prehled-platnych.aspx >.

Zpráva společnosti Mostecká uhelná, a.s. Činnost a udržitelný rozvoj v roce 2006. (Report of Mostecká uhelná, a.s.: Activities and Sustainable Development in 2006.) [online] [cit. 2008-01-06]. Available at: <http://www.czechcoal.cz/cs/profil/mus/rekultivace/index.html>. 
